\title{
genealogy
}

Article

\section{The Roots of Carlos Vaz Ferreira's Philosophy}

\author{
Amy A. Oliver
}

Department of Philosophy and Religion, American University, Washington, DC 20016, USA;

aoliver@american.edu

Received: 10 October 2019; Accepted: 5 November 2019; Published: 8 November 2019

check for updates

\begin{abstract}
Carlos Vaz Ferreira (1872-1958) was Uruguay's leading twentieth-century philosopher. He worked on social and political philosophy, moral philosophy, aesthetics, and feminism. Considered to be one of Latin America's most original thinkers, Vaz Ferreira's philosophy was nonetheless responsive to and, in some cases, influenced by the work of a number of other figures. This article explores Vaz Ferreira's roots in the thought of Herbert Spencer, Charles Darwin, Dr. Gregorio Marañón, Benito Jerónimo Feijóo y Montenegro, Harald Höffding, Hugo Münsterberg, Wilhelm Dilthey, Miguel de Unamuno, John Stuart Mill, William James, José Enrique Rodó, and Henri Bergson. His feminist philosophy was influenced by his sister, María Eugenia Vaz Ferreira, Dr. Paulina Luisi, and other suffragists. I seek to distinguish among the influences Vaz Ferreira ultimately rejected, those he could not escape, those he adapted, and those he most favored as he developed his unique philosophy of freedom.
\end{abstract}

Keywords: experience; phenomenology; psychology; pragmatism; fermentation; evolution; feminism; meliorism; women; suffrage

\section{Background}

Uruguay's leading twentieth-century philosopher, Carlos Vaz Ferreira, wrote on social and political philosophy, moral philosophy, aesthetics, and feminism. Widely considered one of Latin America's most original thinkers, Vaz Ferreira was nonetheless responsive to and, in some cases, influenced by the work of a number of other notable intellectuals.

\section{Methods}

This article explores some of Vaz Ferreira's roots in the thought of Herbert Spencer, José Ortega y Gasset, Miguel de Unamuno, José Enrique Rodó, Harald Höffding, Hugo Münsterberg, Wilhelm Dilthey, Benito Jerónimo Feijóo y Montenegro, Charles Darwin, Gregorio Marañón, John Stuart Mill, William James, and Henri Bergson. In particular, his feminist philosophy was seriously sensitive to the lives of his sister, the poet María Eugenia Vaz Ferreira, poets Delmira Agustini, Juana de Ibarbourou, and Gabriela Mistral, the first woman medical doctor in Uruguay, Paulina Luisi, and other suffragists and intellectuals.

\section{Results}

I distinguish among the influences Vaz Ferreira ultimately rejected, those he could not escape, those he adapted, and those he most favored (Bergson and James) as he developed his philosophy of experience. 
In Meditaciones del Quijote, the Spanish philosopher, José Ortega y Gasset (1883-1955) famously asserted, "I am I and my circumstance; and, if I do not save my circumstance, I do not save myself."1 The Uruguayan philosopher, Carlos Vaz Ferreira (1872-1958), ultimately can be best read as taking a similar stance to Ortega's regarding circumstances. Another Spanish philosopher, Miguel de Unamuno (1864-1936), and Vaz Ferreira engaged in a lively correspondence, and shared many intellectual enthusiasms, yet Ortega was the greater influence of these two distinguished Spanish thinkers (Unamuno and Vaz Ferreira n.d.) Vaz Ferreira read the works of many other European, American, and Latin American philosophers who spoke to some of his preoccupations. Overall, the intellectual roots of Vaz Ferreira's thinking have been influenced less by reading particular philosophers than by his militant focus on his circumstance as an educator and engaged citizen of Montevideo. His university education was seriously formative, though I argue he outgrew and surpassed some of that early training. In his middle years, Vaz Ferreira gravitated most toward concerns, themes, and insights of the French philosopher, Henri Bergson (1859-1941), and the North American philosopher, William James (1842-1910).

In this essay I will outline Vaz Ferreira's early and later intellectual influences, and then argue for the greater impact coming from the particulars of his circumstances in Montevideo. For instance, at a key moment, he advocated for women's rights and helped enact lasting social change. North American philosophy professor John H. Haddox (1929-2017) characterized Vaz Ferreira as a philosopher "whose thought was directly related to action. No 'ivory tower' scholar, he was involved in the promotion of educational reforms and exerted a profound influence on the moral and political life of Uruguay" (Haddox 1966, p. 595).

Many leading Latin American philosophers, such as Arturo Ardao (1912-2003) of Uruguay, Arturo Andrés Roig (1922-2012) of Argentina, and Yamandú Acosta (1949-) of Uruguay, among others, have already closely studied Vaz Ferreira's work and written about numerous of the known and the likely influences on its development. The scope of this article does not allow me to go into such detail, but in an abbreviated account, I will revisit some of the philosophers who have been considered influential, particularly in Vaz Ferreira's major works. I will then turn to some of the people who had impact on a less studied but important volume by Vaz Ferreira, Sobre feminismo (1933).

As a university student in Montevideo, during the rectorship of Alfredo Vázquez Acevedo, Vaz Ferreira was exposed amply to the dominant influence of positivism, particularly the English philosopher, Herbert Spencer's (1820-1903) evolutionism. Generally, positivism involves the philosophical application of scientific methods to human affairs such that what is real is thought to be that which can be measured. Vaz Ferreira's early publications as a young professor, Ideas y observaciones (Vaz Ferreira 1905a) and Moral para intelectuales (Vaz Ferreira 1920), showed evidence of his positivist philosophical and legal training even as they moved beyond it to reveal his growing interest in the psycho-philosophical process of figuring out what one thinks. In a letter from Unamuno to Vaz Ferreira, commenting on Vaz Ferreira's book Ideas y observaciones, Unamuno wrote, "I too suffered from Spencer's disease-what damage has been inflicted by this Spencer, whose spirit is more broad than deep, and afflicted by a true incapacity for real philosophical reflection! — but I cured myself of him and I owe this more than just a little to William James, whom you quote (Unamuno)." (Unamuno and Vaz Ferreira n.d.) ${ }^{2}$ Unlike Unamuno and James, Vaz Ferreira did not expressly loathe Spencer. In his reply to Unamuno, Vaz Ferreira did not reciprocate Unamuno's lament by disparaging Spencer directly even as he almost certainly agreed with Unamuno's critique. Vestiges of positivism imbued Vaz Ferreira's early work. He did not then break explicitly and openly with Spencerian positivism; he simply considered it part of his education, but he soon outgrew and surpassed it, and his mature work took directions that were in stark opposition to positivism, if not militantly or declaredly

All translations are mine unless otherwise noted.

I thank the wonderful staff of the Casa-Museo Unamuno in Salamanca for allowing me access to the original letters. 
so. He realized that Spencer's influence was pervasive and had endured long enough that it would be difficult to gauge the extent to which he was or was not affected by it. Therefore, he simply moved on without publicly casting judgment on Spencer's theories. From these first publications onward, he opposed philosophical systems of all kinds and instead firmly grounded his view that philosophy is relative to particular historical circumstances. John Haddox wrote, "His thought was fragmentary and spontaneous and germinal; he opposed systematizing; he sought to open windows, not to build walls" (Haddox 1966, p. 596).

Often linked to his compatriot, José Enrique Rodó (1871-1917), Vaz Ferreira admired Rodó's emphasis on the American context as opportunity, as described in the latter's landmark essay Ariel (Rodó 1967), as well as his use of language. While Rodó excelled at parables, Vaz Ferreira became a master of metaphors. The Argentine philosopher Arturo Andrés Roig (1922-2012) noted:

Vaz Ferreira inherits the Americanist message from Rodo and perfects it in his writings with a philosophical technique and a critical attitude that the author of Ariel had not attained. Indeed, in the book Pensamiento y accion (1908), Vaz Ferreira responds to the same exigencies that prompted Rodo to defend the existence of our conception of the world and our lives against a tyrannizing USA-mania, but with an important difference: Vaz Ferreira reaches an epistemological level that is noteworthy, rigorous, and clear, and which reveals the intrinsic weakness of pragmatism as a doctrine and consequently of the pragmatic spirit of which it is philosophical expression. (Roig 1981, p. 120)

That said, Vaz Ferreira became increasingly less sceptical about pragmatism as time went by, eventually developing an affinity for its usefulness.

Arturo Ardao has provided excellent analyses of Vaz Ferreira's roots (Ardao 1978). Among the more interesting of the lesser influences that Ardao has traced are those of a wide variety of European thinkers, including Harald Höffding, Hugo Münsterberg, Immanuel Kant, Wilhelm Dilthey, and Benito Jerónimo Feijóo y Montenegro.

Among the early influences Ardao noted are Danish philosopher Harald Höffding (1843-1931), whose Outlines of Psychology privileges the will over knowledge and feeling, the latter two of which he saw as elements of the will (Höffding 1891). As psychology and philosophy continued to distinguish themselves from one another, the German-American psychologist, Hugo Münsterberg (1863-1916), became noted for his influence on applied psychology, especially clinical, forensic, and industrial psychology. William James gravitated to Münsterberg's ideas, which supported James's own theory of emotion. Münsterberg and James met at a conference in Paris in 1891. A year later, James invited him to come to Harvard to run the university's psychology lab. Though a controversial figure, Münsterberg eventually served as president of the American Psychological Association. Vaz Ferreira was similarly attracted to Münsterberg's thought, probably most for its applications to education, which became a dominating concern of Vaz Ferreira.

Turning to more classical figures in the history of philosophy such as Immanuel Kant (1724-1804), Vaz Ferreira became versed in Kantismo and showed a respectful attention to Kant. However, he wished that Kant had given us more than "systematization." In addition to divisions Kant established, such as dividing the spirit into "compartments" and setting up "partitions," Vaz Ferreira longed to know more about what Kant doubted, what he did not know, and above all, how he approached thinking about what he did not understand, or his process of thinking through problems.

The German philosopher, Wilhelm Dilthey (1833-1911), who arguably had a much wider audience in Latin America than in North America, rejected traditional associationist psychologies (theories that conceptions can be deduced from the traces that sensations leave in the brain) in favor of a descriptive psychology (a conceptual framework for modern psychological science) that lay the foundation for phenomenology. For Dilthey, expressions of action and thought were crucial for understanding. Vaz Ferreira developed consciousness of this trend and incorporated it into his own notion of psychology, which he called psycho-logic.

In an insightful but understudied essay called "Vaz Ferreira y Feijóo" (Ardao 1993), Ardao explored a series of striking similarities between the two thinkers, which could seem surprising because 
the men were separated by centuries and the Atlantic Ocean. The Spaniard, Benito Jerónimo Feijóo y Montenegro (1676-1764), and Vaz Ferreira shared convictions about moderate skepticism, rejection of dogmatism, questions of words versus questions of fact, reason based in experience, and verbal argumentation. Vaz Ferreira's father, who was a businessman, hailed from Valença do Minho in northern Portugal, very close to Feijóo's Galician home. Ardao suggests that Vaz Ferreira seems to manifest Feijóo's influence, even though there is no textual evidence to support this idea.

The Uruguayan commentator Manuel Claps argued for four decisive influences on Vaz Ferreira: Spencer, Mill, James, and the French philosopher and poet, Jean Marie Guyau (1854-1888), with the last not usually considered by other critics as a primary influence. Claps posited that two of Guyau's works, Esbozo de una moral sin obligación ni sanción and La irreligión del porvenir (Guyau 1904, 1911), appear inspirational for Vaz Ferreira's Conocimiento y acción.

In addition to Herbert Spencer's ideas, which had circulated widely, so too did the ideas of Charles Darwin and the Spanish medical doctor and essayist, Gregorio Marañón (1887-1960). Professors Adriana Novoa and Alex Levine observed, "By the end of the nineteenth century, the language of Latin American political and intellectual discourse was replete with biological analogies" (Novoa and Levine 2010, p. 14). Novoa and Levine cite Rodolfo Rivarola, who noted in 1908, "the concept of evolution, as it applies to organic matter, may be easily translated to the realm of social thought and action" (Novoa and Levine 2010, p. 234). The Cuban philosopher, Raúl Fornet-Betancourt (1946-) postulated that Vaz Ferreira's thinking was also influenced by the Darwinian science of the day and notions of women's biology put forth by figures such as Dr. Gregorio Marañón. Although Vaz Ferreira classified Dr. Marañón as an antifeminist, Marañón's ideas about sex were widely circulated (Fornet-Betancourt 2009, p. 27). As Spencer's ideas fell out of favor, the work of Henri Bergson (1859-1941) on vitalism gained traction and began to replace positivist thought. The North American political philosopher, Michael A. Weinstein (1942-2015) wrote of Bergson, "His notion of spontaneous and imprevisible creative evolution freed the concept of becoming from subordination to static truth systems" (Weinstein 1976, p. 17). Vaz Ferreira attributed to Henri Bergson and William James the opening up of psychic life, "that fluid mental reality that cannot be expressed through logical thinking," or language. This psiquismo attracted scientists and artists alike (Vaz Ferreira 1905b, p. 164).

The pragmatism of William James had a pronounced impact on Vaz Ferreira, especially on his feminist philosophy. Both thinkers were deeply attracted to psychology and its intersections with philosophy. Although Vaz Ferreira initially expressed some significant criticisms of James's pragmatism, at the same time he greatly admired James, who, together with Henri Bergson, provided the impetus that transformed Vaz Ferreira from a young philosopher schooled in Spencerian positivism into an initial, resisting pragmatist, then into a crypto-pragmatist, then a quasi-pragmatist, and finally, at times, a true pragmatist. Vaz Ferreira's thought evolved to a point at which he consented to call himself a feminist, though he did not also call himself a pragmatist, reserving that term to denote the thought of Peirce, James, and Schiller. Instead, Vaz Ferreira classified himself as a philosopher of experience.

In terms of intellectual ancestry, Vaz Ferreira's Lógica viva (1910) descends from John Stuart Mill and Herbert Spencer (Vaz Ferreira 1958b, p. 4). Finding better company among the works of Nietzsche, Bergson, James, and Unamuno, Vaz Ferreira embraced empiricism, a theory that privileges sensory experience, as its point of departure and source of knowledge, and as the primary focus of reflection. His philosophy of experience was opposed to abstraction in language, generalization, systematization, and speculation. Instead, his philosophy of experience valued lived spontaneity of thought in the immediate reality of consciousness, and knowledge linked to action.

Among the works of William James that Vaz Ferreira cited are The Will to Believe, The Varieties of Religious Experience, Pragmatism, The Principles of Psychology, and Talks to Teachers on Psychology and to Students on Some of Life's Ideals. Of all of these works, Vaz Ferreira was most impressed by chapter nine of The Principles of Psychology, "The Stream of Thought." This concept greatly intrigued Vaz Ferreira and he praised it often. Other valuable ideas Vaz Ferreira found in pragmatism were de-emphasizing 
language or word play, emphasizing the concrete, focusing on questions such as the immortality of the soul, and, finally, respecting different ideas, feelings, and experiences.

However, Vaz Ferreira also had some very serious criticisms of pragmatism at his first encounter with some of its central tendencies and assumptions. He developed his objections in three essays published individually in 1908 and 1909 and later collected in one volume, Conocimiento y acción, published in 1920. Vaz Ferreiras's two primary "concerns" with pragmatism, rather than representing mere quibbles, amount to an initial rejection of pragmatism. For instance, in religious questions, Vaz Ferreira thought that James used reason to force belief and that James was only concerned with immediate consequences when he should also have allowed for the possibility of long-term consequences. Secondly, Vaz Ferreira objected to the devaluing of theory when it did not have immediate practical consequences. His early Spencerian education may have made him fundamentally resistant to critiques of the rational. He did not want to let go entirely of rationalism, the use of reason as the primary basis for knowledge, even as he was increasingly drawn to James's empiricism and began to take a pragmatist turn. Vaz Ferreira also perceived another deficiency in James's work, a north-south cultural gap of the sort highlighted in the work of José Enrique Rodó: that there was a Latin American cultural tradition which held that pursuit of truth was a valuable enterprise in and of itself, whether such pursuits ended up being useful or not. There was, Vaz Ferreira thought, a difference between North Americans and South Americans about what could be considered "useful."

Vaz Ferreira's detailed critiques of specific passages on pragmatism by James were not always clearly argued. What was clear was that James initially disturbed Vaz Ferreira. James's ideas represented a paradigm shift that Vaz Ferreira had difficulty embracing even as pragmatist thought began to consume him. This possibility is borne out by the phenomenon that Vaz Ferreira's works became increasingly pragmatist in spirit after he wrote his initial critiques of pragmatism in 1908 and 1909. For example, in his books Lógica viva (1910) and Fermentario (1938), Vaz Ferreira stressed writing as a process and argued for "more amorphous" publications. Vaz Ferreira was himself following Henri Bergson's description of ideas that "follow the sinuous and mobile contours of reality." The mind, "continually guided by a series of nascent movements [ ... ] which translate symbolically the thousand successive directions of the thought" moves along "a curve of thought and feeling analogous to that we ourselves describe" (Bergson 1920, vol. 6, pp. 55-57). In pursuit of Bergson's idea, Vaz Ferreira favored writings that evidenced their stages of "fermentation" (e.g., the psychological fringe, the penumbra, the "halo" around absolute clarity). As Arturo Ardao noted, "Vaz Ferreira draws our attention to thought that is not crystallized or defined, but is in a nascent, germinal, or fermentary state" (Ardao 1961, p. 33). Relatedly, in Conocimiento y acción, Vaz Ferreira wrote, "What we express is no more than a minimal part of what we think." What we think, in turn, "is a minimal part of what we feel" (Vaz Ferreira 1958a, vol. 8, p.99). Adriana Novoa writes that Vaz Ferreira

[... ] explained that thanks to Bergson and James, psychism (psiquismo) was now not understood as discourse, but 'as a fluid mental reality' that was not an expression of logic. It was the expression of what was not representable in the traditional understanding of rationality, even when it 'was common to all men' and was the true treasure of humanity. But Vaz Ferreira also recognized that the capture of the flow of life through nondiscursive methods complicated the desire for truth, and even promoted among some who practiced it 'fraud, exaggeration, artifice, pose, and snobbism.' He noticed that the emphasis that Bergsonism gave to subjectivity might be extremely dangerous, particularly in the view of those devoted to the hard sciences and materialism. (Novoa 2019, p. 160)

In addition to coming to understand thinking, writing, and being as dynamic processes, Vaz Ferreira also exhibited an affinity for two other central themes in classical American philosophy: meliorism-the view that human action can improve the human condition - and the centrality of community and the social. These themes were prominent in his writings on ethics, education, and feminism. In much the same way that James was anxious to uncover what beliefs amount to in human life, what their "cash value" was in Jamesian terms, or what consequences and actions they led to, Vaz Ferreira examined 
feminism with an aim toward culling from it what was going to be effective for improving the lives of the women and men who surrounded him.

As movements, pragmatism and feminist philosophy have frequently generated complementary ways of thinking. Both sensibilities encourage active forms of doing philosophy and take immediate, surrounding social realities and experience as their point of departure for reflection. Education and egalitarian social reforms have often been areas of interest for pragmatists and feminists. Belief in the malleability of the social environment and the possibility of meliorism through thought and action pervade much of both pragmatism and feminism. North American philosophers, Shannon Sullivan, Richard Rorty, and Charlene Haddock Seigfried have written on this interplay between pragmatism and feminism (Sullivan 1993; Sullivan 2001; Rorty 1991; Seigfried 1996).

The cultural and political climate in Montevideo during key periods in Vaz Ferreira's life served to support his ideas. During the two presidencies of José Batlle y Ordóñez (1903-1907 and 1911-1915), Uruguay became the first country to legislate the eight-hour workday, the first to guarantee health care to the poor, and the home of a social security system that served as a model for the rest of the continent. Vaz Ferreira, in the context of this progressive political climate in Montevideo, was the first Latin American philosopher to publish a book with "feminism" in its title, Sobre feminismo. Changes in the law also made it easier for women to divorce and gain access to higher education and social services, and in 1932 Uruguay became the second Latin American nation to grant women the vote in national elections (after Ecuador in 1929). Vaz Ferreira's feminist thought was complementary to this progressive cultural moment as symbolized by politicians such as Batlle y Ordóñez and Baltasar Brum. According to North American historian, Katherine M. Marino, “Brum and a number of statesmen from his progressive Colorado Party absorbed the well-worn nineteenth-century socialist idea that civilization could be measured by women's rights. Women's suffrage, they believed, would enhance Uruguay's democracy and power in the world" (Marino 2019, p. 21). Vaz Ferreira was himself an important agent of change during this era. Concerned with the civil and political rights of women and the social participation of women, Vaz Ferreira, working with many others, had a decisive impact in favor of women in Uruguayan legislation. For example, Vaz Ferreira authored a bill that passed into law exactly as he had conceived it: the law of "unilateral divorce," which gave "women the power to obtain a divorce at will, without giving cause, while men have to show just cause" (Vaz Ferreira 1958, vol. 9, p. 83). This situation was consistent with his theory that men and women experience life in fundamentally different contexts. When the law passed, "opponents of divorce did not like it because of their need to preserve the family as the basis of society. Proponents of the right to a divorce did not like it either because they framed the question as one of 'equality'" (Vaz Ferreira 1958, vol. 9, p. 83).

Beginning in 1914, Vaz Ferreira delivered a series of lectures on feminism. He was primarily concerned with examining "factual" differences between the sexes and with "normative" issues such as the political and civil rights of women, the social life of women, and the organization of the family within society. Vaz Ferreira analyzed the disproportion between the ideas and faculties of women and the scope that society allowed to their activity. He advocated the right of women to participate in all that makes life valuable to the human being. His lectures continued until 1918, then resumed in 1922, but were not published in book form until 1933 because the Universidad de la República's stenographic service was not maintained for a number of years. ${ }^{3}$ Subsequent editions of Sobre feminismo appeared in 1945, 1957, and 1963. He expressed ideas in this work that were timely, relevant, far-sighted, and innovative in light of contemporary social debates throughout the Americas.

Vaz Ferreira's philosophical training led him to be more careful to observe and theorize empirically and rationally what a good feminist society would look like. His social interactions involved his

3 Vaz Ferreira's lectures on feminism were lost while the transcription service was unavailable and he reconstructed them from memory closer to the 1933 publication, but he conceded that much was missing from the original lectures. He gave a series of talks on Bergson, which, tragically, were also lost but not reconstructed. Had the talks been reconstructed and published, they would surely give us greater insight into how Vaz Ferreira experienced Bergson's influence. 
support for the careers of women he knew personally: he encouraged women's intellectual successes. In addition to supporting the work of the Uruguayan poet, Delmira Agustini (1886-1914), and other women, Vaz Ferreira served on a committee that organized a tribute to another Uruguayan poet, Juana de Ibarbourou (1892-1979), who was nominated for the Nobel Prize for Literature four times. In 1945, he served as head of the committee that planned a tribute to the Chilean poet, Gabriela Mistral (1889-1957), the first Latin American Nobel Laureate. Again in 1954, he helped facilitate Mistral's visit to Montevideo. When Vaz Ferreira's sister, the talented poet, María Eugenia Vaz Ferreira (1875-1924), fell ill and, as her illness worsened, he helped her select poems to be published after her death in a volume entitled La isla de los cánticos. He ensured that the book was published. These acts modeled the feminist behavior in which Vaz Ferreira believed men should engage.

During Vaz Ferreira's life, as Uruguay transitioned from the nineteenth to the twentieth century, a number of key simultaneous conditions obtained. Industrialization was becoming established, important immigrant contingents began arriving, primarily from Spain, Portugal, Italy, and France, and democratic, anarchist, communist, and socialist ideas were widely gathering attention and adherents. Feminism emerged somewhat late in Uruguay, partly, I would argue, because few women had reached the university until the beginning of the twentieth century. One of those pioneering women was Paulina Luisi (1875-1950), the first woman to become a medical doctor in Uruguay (1908), and the first feminist to be widely recognized as an activist in Montevideo. ${ }^{4}$ She led The Uruguayan National Council of Women in 1916, which campaigned for women's suffrage. She directed the feminist journal Acción Femenina, the only such journal until 1937. Her sisters were also independent and accomplished. Clotilde was the first woman to become a lawyer (1911), Luisa was a well-known poet, Inés also became a doctor, and Anita and Elena were teachers. María Eugenia Vaz Ferreira was also a friend of Luisa Luisi. Both María Eugenia and Carlos knew the Luisi family.

To remedy the early dearth of women at the University, a progressive President of Uruguay, José Batlle y Ordóñez, founded the University for Women in 1912. A few years later, the university enrolled 750 students. In 1915, María Eugenia Vaz Ferreira was appointed Professor and Chair of Literature there. In 1918, Alicia Goyena Wetzstein was appointed to teach history when a substitute was needed. Thus, two women managed to teach at the University for Women close to its inception, and one held a leadership role she would not likely have had in a coeducational university. In 1922, however, María Eugenia Vaz Ferreira had to resign from her position when her kidney disease worsened, but not before she hand-picked her successor, Alicia Goyena. When the 1933 dictatorship threatened the university's progress, Goyena participated in the resistance alongside Carlos Vaz Ferreira, who was elected Rector of the Universidad de la República for a term from 1935 to 1941. Vaz Ferreira was a strong advocate for university autonomy, which those in the dictatorial regime questioned. In 1944, Goyena became director of the Instituto Batlle y Ordóñez, where she implemented Vaz Ferreira's ideas on pedagogy over the next 32 years. $^{5}$

Vaz Ferreira was also concerned about the plight of single women in Uruguayan society, and defended the right of women to choose to remain single without society looking askance: "The horrible part is that society is organized around making pariahs of women who do not marry (Vaz Ferreira 1958, vol. 9, p. 92)." The social pressure suffered by his sister, María Eugenia, did not escape Vaz Ferreira's attention when she chose to remain single and defy familial and societal expectations. She appears to have been a lesbian, a detail seemingly not publicly discussed, because, in her time and social class, Montevideo was not Paris or Berlin. Vaz Ferreira came close to explicitly

4 Another early feminist born in Uruguay was María Abella de Ramírez (1863-1926). However, she spent the majority of her life in La Plata, Argentina.

5 Alicia Goyena had to step down at age 79 because a law was passed that required retirement at 70 . She continued to be active as emerita, maintaining an office at the Liceo Femenino. On her 80th birthday, at 09:00 h, the military expelled her by force, despite the efforts of Associate Director Margarita Mendoza, who put herself between Alicia and the soldiers. See (Ferro 2008). 
naming and supporting lesbianism when he wrote of women who do not marry, women "who have a different ideal, whatever it may be: dedication to science, art, or a social cause; or even to a different sexual ideal" (Vaz Ferreira 1958, vol. 9, p. 144). Throughout her life, María Eugenia's single status sometimes received more attention than her literary works, some of which were published and studied more widely after her death. Uruguayan cultural critics referred to her as a virgen otoñal (autumnal virgin). Additionally, her brother, while skilled at defending the rights of single women, understood the pressures suffered by married women in oppressive relationships. This was yet another reason why he supported a woman's right to divorce for "irreconcilable differences," without further explanation or elaboration.

Vaz Ferreira's interest in feminism developed in the early teens of the twentieth century for three primary reasons. The progressive political climate in Uruguay fostered feminist ideas. There was also a worldwide discussion of women's suffrage at that time. Perhaps most significantly, he watched his sister suffer in many ways because she remained unmarried and was suspected of being a lesbian. Beyond his circumstances, however, he developed feminist ideas because he took the time to study these ideas as seriously and comprehensively as he dealt with any other ideas or movements. He addressed many more issues than voting rights as he developed a thoroughgoing feminist philosophy.

\section{Conclusions}

Vaz Ferreira probably benefited in one way or another from most of the intellectuals who influenced him, including those who irked him. From Bergson and James, he learned how best to think and what to pay attention to while analyzing controversial social topics of the here and now. From reading his sister's poetry and that of other talented women authors, and from observing the problems women faced in their daily lives, Vaz Ferreira developed a feminist perspective that was a precursor of what is today called "difference feminism."

He applied philosophical rigor as seriously to women's issues as he did to other traditional philosophical issues. Feminism was not a sideline or just a political issue of the day for him. It was a key area ripe for reflection. Conscious of his prestige and standing as a premier public intellectual, philosopher, and university official, he leveraged that standing to effect change for women by raising consciousness, giving public lectures beginning in 1914, supporting suffrage, drafting legislation that passed, and publishing Sobre feminismo in 1933. He was not intimidated by the fact that many other men thought feminism was not a topic worthy of his attention.

Vaz Ferreira positively modeled a moral voice through his engagement with public philosophy. He delivered public lectures in Montevideo and published essays in the newspapers, taking a stand on the issues of the day. In part because of his consciousness of nation building, widespread in Latin America during the century or so following the wars of independence, for the sake of enhanced social reform, Vaz Ferreira cast a critical gaze over his fellow citizens of Uruguay and recommended ways their lives should change. His critical expression exposed fundamental questions about his moral stance: most basically, he manifested an ability, while himself privileged, to identify with and be an advocate for people of marginalized groups of which he was not a member (women, children, people of other social classes, etc.). Considering the pluralistic social reality that obtains in many situations today, his example can illuminate how we might recognize and achieve sympathetic identification with members of very different groups.

His highly visible public roles call into question the assumption that empathetic advocacy can only come from similarly situated peers. Social cohesion without such empathetic moral identification is arguably impossible, very difficult, or undesirable. For instance, it is easy to claim that Vaz Ferreira's sister and her situation in history stirred him to care for the improvement of women's circumstances, yet he cared about the entire category of women, not just because he saw his sister as not properly respected.

Vaz Ferreira persisted in and explored implications of his philosophy of experience. Demonstrating more than flashes of empathy, Vaz Ferreira developed a life-long commitment, one of the best models for moral consistency and constancy. In Kantian terms, Vaz Ferreira acted in such a way that his 
example could become a plausible and useful one. Above all, his model resists dogmatism and encourages "fermentative" thinking. While it is possible to identify many of the roots of Vaz Ferreira's philosophy, the sum total of such roots finally serves to underscore the originality of his thinking, and encourage his readers to tackle preoccupations we have with our own experience and circumstance.

Funding: This research received no external funding.

Conflicts of Interest: The author declares no conflict of interest.

\section{References}

Ardao, Arturo. 1961. Introducción a Vaz Ferreira. Montevideo: Barreiro y Ramos, S.A.

Ardao, Arturo. 1978. Ciencia y metafísica en Vaz Ferreira. In Estudios latinoamericanos: Historia de las ideas. Caracas: Monte Ávila, pp. 197-213.

Ardao, Arturo. 1993. Vaz Ferreira y Feijóo. Cuadernos de Marcha 90: 5-8.

Bergson, Henri. 1920. Mind-Energy. Translated by H. Wildon Carr. New York: Henry Holt.

Ferro, Margarita. 2008. Alicia Goyena: Una pedagogía para la vida. Montevideo: Consejo de Educación Secundaria.

Fornet-Betancourt, Raúl. 2009. Mujer y filosofía en el pensamiento iberoamericano: Momentos de una relación difícil. Barcelona: Anthropos.

Guyau, Jean Marie. 1904. Esbozo de una moral sin obligación ni sanción. Montevideo: Claudi García y Cía.

Guyau, Jean Marie. 1911. La Irreligión del porvenir. Madrid: Daniel Jorro.

Haddox, John H. 1966. Carlos Vaz Ferreira: Uruguayan Philosopher. Special issue. Journal of Inter-American Studies 8: 595-600. [CrossRef]

Höffding, Harald. 1891. Outlines of Psychology. Translated by Mary E. Lowndes. London: Macmillan. Co., Originally published in Copenhagen.

Marino, Katherine M. 2019. Feminism for the Americas: The Making of an International Human Rights Movement. Chapel Hill: The University of North Carolina Press.

Novoa, Adriana. 2019. Racial Becomings: Evolution, Materialism, and Bergson in Spanish America. In Beyond Bergson: Examining Race and Colonialism through the Writings of Henri Bergson. Edited by Andrea J. Pitts and Mark William Westmoreland. Buffalo: State University of New York Press.

Novoa, Adriana, and Alex Levine. 2010. From Man to Ape: Darwinism in Argentina, 1870-1920. Chicago: University of Chicago Press.

Rodó, José Enrique. 1967. Ariel. Edited with an Introduction and Notes by Gordon Brotherston. Cambridge: The University Press. First published 1900.

Roig, Arturo Andrés. 1981. Teoría y crítica del pensamiento latinoamericano. México: Fondo de Cultura Económica.

Rorty, Richard. 1991. Feminism and Pragmatism. Michigan Quarterly Review, Spring. Ann Arbor: University of Michigan.

Seigfried, Charlene Haddock. 1996. Pragmatism and Feminism: Reweaving the Social Fabric. Chicago: University of Chicago Press.

Sullivan, Shannon. 1993. Hypatia Special Issue: Feminism and Pragmatism, Spring. Bloomington: Indiana University Press, vol. 8, no. 2 .

Sullivan, Shannon. 2001. Living Across and Through Skins: Transactional Bodies, Pragmatism and Feminism. Bloomington: Indiana University Press.

Unamuno, Miguel de, and Carlos Vaz Ferreira. n.d. Undated Correspondence. Salamanca: Casa-Museo Unamuno. Vaz Ferreira, Carlos. 1905a. Ideas y observaciones. Montevideo: A. Barreiro y Ramos.

Vaz Ferreira, Carlos. 1905b. Reacciones. Nosotros 2. no. 9.

Vaz Ferreira, Carlos. 1920. Moral para intelectuales. Montevideo: Imprenta "El Siglo Ilustrado". First published 1908.

Vaz Ferreira, Carlos. 1958a. Conocimiento y acción, Obras: Homenaje de la Cámara de Representantes de la República Oriental del Uruguay. Montevideo: House of Representatives, vol. 8.

Vaz Ferreira, Carlos. 1958b. Lógica viva, Obras: Homenaje de la Cámara de Representantes de la República Oriental del Uruguay. Montevideo: House of Representatives, vol. 4. 
Vaz Ferreira, Carlos. 1958. Sobre feminismo, Obras: Homenaje de la Cámara de Representantes de la República Oriental del Uruguay. Montevideo: House of Representatives, vol. 9. First published 1933.

Weinstein, Michael A. 1976. The Polarity of Mexican Thought: Instrumentalism and Finalism. University Park: The Pennsylvania State University Press.

(C) 2019 by the author. Licensee MDPI, Basel, Switzerland. This article is an open access article distributed under the terms and conditions of the Creative Commons Attribution (CC BY) license (http://creativecommons.org/licenses/by/4.0/). 